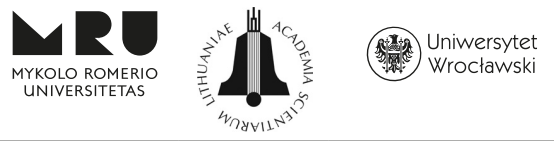

\title{
IMPACT OF DIFFERENT QUALITY MANAGEMENT SYSTEM IMPLEMENTATION PATTERNS ON PERFORMANCE OUTCOMES
}

\author{
Adolfas KAZILIŪNAS
}

Mykolas Romeris University

E-mail: adkazyl@cablenet.lt

Lina VYŠNIAUSKIENĖ

Mykolas Romeris University

E-mail: lvysnia@mruni.eu

doi:10.13165/IE-14-8-1-10

\begin{abstract}
Literature indicates that organisations often lack flexibility in the design and implementation of quality management systems and show a low utilisation of employee skills and knowledge. This article analyses different patterns of the implementation of quality management systems in different kinds of organisations and examines the performance outcomes associated with it. The research shows that organisations with different quality management system implementation patterns have significantly different performance outcomes. A mature quality management system should consider success factors for quality management system implementation benefits from the early phases of their planning and designing processes. There is an interesting relationship between reasons of ISO 9001 quality management system implementation and the corresponding performance outcomes. By requiring that all processes and procedures be documented, the ISO 9000 standard is undoubtedly commonly associated with control orientation and explicit knowledge orientation organisations. By implementing organisational learning mechanisms, organisations can increase the capability of managing and utilising knowledge. Such mechanisms allow organisations to collect, analyse, store, disseminate and use information that is relevant to the organisation. Correct maintenance of quality management system during the post-certification period is very important. Quality auditors are in a powerful position to increase the value of quality management systems. Value-added audit may not only produce data for the use in granting a certificate, for improving documentation or for enforcing conformity, but also for making managerial decisions concerned with economy, staff development, technology, growth, product and processes, because these decisions are based on current performance.
\end{abstract}

JEL. Classification: L00, L1, L15.

Keywords: quality management systems, ISO Standards, quality management, knowledge management.

Reikšminiai žodžiai: kokybès vadybos sistemos, ISO standartai, kokybės valdyba, žinių valdyba. 


\section{Introduction}

The ISO 9000 family of standards has been developed to assist any organisation in all sectors regardless of size, type and activity to implement and operate effective quality management systems. Using international standards benefits manufacturers, service providers, users, consumers and regulators and supports sustainable development. Quality management systems based on international standards provide confidence and facilitate access to world markets, their popularity thus is as relevant today. By looking at the number of ISO 9001 certificates per 1000 inhabitants one can see that Italy is the leader (1.70), followed by Spain (1.11) and Australia (0.84), UK (0.76), Germany (0.48), Japan (0.42), France (0.40) (Sampaio et al. 2009).

The quality management systems complying with ISO 9001 standards have also gained recognition in Lithuania. The number of ISO 9001 certifications has substantially increased in the last few years. By the end of July 2013, ISO 9001 had approached 1,220 certifications across a wide range of organisations in the manufacturing, service and governmental areas. The number of ISO 9001 certificates per 1000 inhabitants in Lithuania reached 0.34 . Companies interested in ISO certification more often receive not only ISO 9001 but also ISO 14001 certificates. However, a comparatively large number of companies are not yet ISO 9001 certified in Lithuania (Mikulis and Ruževičius, 2009).

Lithuanian businesses and organisations of all kinds have been rapidly changing over recent years. Organisations and companies are becoming increasingly dependent on each other and foreign partners for business, prosperity, socio-economic change and environmental responsibility. To remain effective and relevant, standardisation and standards processes need to meet the changing expectations of industry, regulatory authorities, society and multiple stakeholders. There is an essential necessity for using international standards in these changing conditions.

Despite numerous success stories of ISO 9000, a considerable deal of criticism of the certification exists, as it is not a risk-free undertaking. ISO 9000 certification does not guarantee improved performance due to high explicit and implicit costs associated with its implementation (Van der Wiele et al., 2005). Lately, various studies have confirmed that ISO 9000 certification is too expensive, time and resource-consuming, formalised and impersonal and that the implementation costs are greater than the benefits derived (Bhuiyan and Alam, 2005; Casadesus and Karapetrovic, 2005).

Concerning the service sector, Dick et al. (2002) have concluded that ISO 9001 quality system implementation makes a strong difference in the ways quality is perceived and measured. Studies do not generally address what happens after the organisations have implemented their quality management system (Ab Wahid and Corner, 2009). In this connection, it can be stated that organisations can implement their quality management system in very different ways. To have more benefits from the ISO 9000 quality system, organisations may take into consideration that the design and implementation of an organisation's quality management system is influenced by organisation's strategy, size and organisational structure, its organisational environment, changes in that environment, and the risks associated with that environment. 
The purpose of this article is to analyse different patterns of implementation and maintenance of quality management systems in organisations which can help planning and implementing quality management systems according to ISO 9000 standards in the most successful way.

The current research is based on qualitative methods of analysis and literature review of quality management practice.

\section{The relationship between organisation's certification motivations and the corresponding results}

The majority of organisations implement the ISO 9001:2008 quality system for several reasons. First, it can be seen as a means of improving internal processes and products or service quality. Second, it can be driven by the adopting organisation as a means or route to increase their domestic or foreign market share, where ISO certification has a value. Third, it may be driven by a customer request to conform to their internal quality control and supplier quality assurance system (White et al. 2009). Organisations that view certification as an opportunity to improve internal processes and systems, rather than simply hang a certificate on the wall, will get broader positive results from ISO 9000 quality management systems (Lopis and Tari, 2003). Swedish investigators Lundmark and Westelius (2006) have revealed that the strongest, most obvious and most valued effects of the ISO 9000 quality management systems are clearer and more apparent working procedures and responsibilities. The most apparent problem is bureaucracy, which can lead to reduced flexibility.

ISO 9001 quality system benefits can be classified into external and internal categories. The former are related to improvements in terms of marketing and promotional aspects, customer satisfaction and market share, while internal benefits are related with organisational improvements, the reward system, team work, measurement of performance and communication, and continuous improvement (Douglas et al., 2003; Gotzamani and Tsiotras, 2002).

As an external motivation factor, ISO 9001 certification is frequently used mostly as a marketing tool (Poksinska et al., 2006). Some companies admit that without ISO 9000 certification they would not have achieved a significant number of contracts (Douglas et al., 2003). Based on survey results, Bhuiyan and Alam (2004) have concluded that as for US companies, one of the most important underlying reasons for becoming certified is the existence of commercial relationships with European markets. Customer pressure is also one of the major motivations to achieve ISO 9000 certification mentioned by companies (Martinez-Costa and Martinez-Lorente, 2003). A strong relationship between company certification motivations and the corresponding results was revealed. When firms simply react to external pressures for getting certified, they may consider ISO 9000 certification as a prime goal in itself, adopt a minimalist approach to achieving it and thus achieve limited internal performance improvements (Quazi and Jakobs, 2004). Rodriguez-Escobar et al. (2006) analysed the dissatisfaction that ISO 9000 created in small companies. For small 
companies, certification is only a guarantee that a company is using a quality management system according to a list requisites and procedures. However, the benefits that have been attributed to ISO 9000 have often been overstated, so that companies tend to generate high expectations that are difficult to realise completely. Biazzo (2005) suggests that there must be an evolution towards the so-called performance/management audit model, in order to increase the ability to unveil conformity and thus increase the value of certifications. The evolution of the logic of audits takes on particular importance in the context of small and medium-sized enterprises since these companies tend to implement formal quality systems only when there is significant external pressure to do so, and when they do, their approach to implementation of ISO 9001 standards tends to be minimalist.

Fotopulos and Psomas (2010) have investigated ISO 9001:2000 implementation in the Greek food sector and have shown that the major reasons for certification, unlike benefits, firstly concern the internal business environment and then the external one, and no particular difficulties were observed during the implementation of the standard. From the overall findings of the study, the authors have concluded that strong internal motivation or willingness to improve a company's quality helps to establish a quality managements system that leads to external benefits, such as improvement of the company's position in the market, as well as to internal benefits. Ruževičius et al. (2004) obtained similar results. Their research revealed that the implementation of quality management system mostly resulted in benefits of an intangible nature that are internal to a given company. The key finding is that although the main reasons to start implementing a quality system are the expectations of external advantages, the implementation results mostly in the increase of internal benefits, such as improvements in the definition of responsibilities and obligations of the employees, a decrease in non-conformism, better communication among the employees, and increased efficiency.

White et al. (2009) examined the rationale for establishing a quality management system by obtaining ISO 9001:2000 certifications in non-profit small to medium enterprises in the UK and showed that through a correct development of a quality management system a company was able to generate bottom-line savings and business performance enhancement. The study identified the process of the preparation for certification and showed that when the quality management system is developed as part of a coherent initiative, lasting performance improvements are achieved.

\section{The impact of organisational structure and management orientation}

The implementation of a quality management system and its subsequent certification is a voluntary process supported by the organisation's own strategy, motivations, policies and goals. To have more benefits from ISO 9000 certification, organisations may take into consideration that the design and implementation of an organisation's quality management system is influenced by the organisation's strategy, its size and structure, organisational environment and its changes as well as the risks associated with that environment (EN ISO 9001:2008, 2008). In this connection, it can be stated that although ISO 9000 has become a common knowledge in organisations and the standard is widely adopted in different 
industries and sectors, it can be a source of competitive advantage, because ISO certified organisations can implement the standard in very different ways.

Some articles analyse the relationship between the values and requirements that underpin the ISO 9000 standard and important strategic and organisational dimensions. The control or creativity orientation is an important dimension that underpins many strategic management choices of organisations (Ghani et al., 2002). Control orientation organisations are synonymous with bureaucracy and are centralised, they have extensive departmentalisation, high formalisation and mainly downward communication, they use a process-oriented strategy, while operational excellence is mainly marked by a highly disciplined and structured way of doing business. The ways of solving and sensing problems can be reduced to a set of explicit systems and instructions. By requiring that all processes and procedures be documented, the ISO 9000 standard is undoubtedly commonly associated with control orientation organisations (Molina et al., 2004). The standard enhances the control of the management system by documentation and formalisation (manuals, procedures, instructions, protocols etc.) and systematisation (hierarchical, orderliness, sequentially interacting processes) (Anwar and Jabnoun, 2006). Organisations of this type derive benefits from ISO 9000 certification very easily.

On the opposite side of the strategic spectrum are creativity orientation organisations. This model of organisation uses cross-hierarchical, flexible and functional teams, has law formalisation, lateral, upward and downward communication systems, and almost continually searches for market opportunities and accordingly institutes or needs to institute highly flexible structures and practices (Donaldson, 2001). The normative values of institutionalisation, documentation and systematisation embodied in the ISO 9000 standard will militate against the need for structural fluidity to stimulate creativity and innovation (Mallak et al., 1997). Organisations of this type introduce some difficulties in implementing quality management systems according to the ISO 9001 standard.

Abdullah and Ahmad (2009) analysed the fit between organisational structures, management orientation, knowledge orientation, and the values of the ISO 9000 standard. They postulated that the more mechanistic and explicit knowledge based organisations will enjoy ISO certification, the more organic and tacit knowledge organisations will experience tensions arising from lack of fit. Hence, conceptually, the standard will work best in more mechanistic and routine knowledge-based settings. Creativity-oriented strategies will find the standard quite dysfunctional, while control and operation-based strategies are likely to benefit most from certification. Same organisations are faced with two conflicting imperatives. The structure tends to be more mechanistic like the public universities, but the knowledge is more tacit. The standard will cause the processes to be agreed, defined, structured, approved, monitored and yet the quality of education will not be fully assessed, as many tacit elements are not subject to easy explicitisation. The standard tends to fit in and also intensify the mechanistic nature of these organisations but also seeks to explicitise the processes. Teaching processes have been structured and standardised much to the chagrin of the educationists and pedagogies in universities. The universities slowly suffer the growing incompatibility of the standard and the tacit knowledge of this sector (Abdullah and Ahmad, 2009; Hazman and Sarina, 2008). 
It is clear that quality has emerged as a strategic competitive tool for organisation's success in the manufacturing, service and governmental areas (Ruževičius and Kasperavičius, 2008). In today's business environment, organisations cannot afford to ignore the strategic implications of quality for their competitive position. Lee et al. (2009) analysed the implementation and performance outcomes of ISO 9000 in service organisations and showed that managers in organisations should realise that ISO 9000 is capable of generating a competitive advantage only if top management is fully committed to programme implementation from a strategic perspective. The most important factor is the way that certification is perceived by top/senior management, as this is classified as the most influential factor for implementing the standard. If certification is perceived in a negative way, top management will not implement the standard, and, at the same time, if the standard is perceived positively, top management will provide their full support to ISO 9000 certification. This is evident from the fact that top management acts as a driver of implementation of quality management systems through the provision of needed resources and the key to continuous improvement through the creation of values, goals, and systems to satisfy customer expectations and to improve organisation performance (Chin and Choi, 2003).

Some authors classify organisations into three categories of strategic orientation, namely, cost leadership, market differentiation and focus strategy, and conclude that strategic orientation is a moderating factor influencing the relationship between registration to a quality scheme, such as the ISO 9000 and the organisation's financial performance (Dimara et al., 2004).

The latest version of ISO 9000 indicates that the standard is constituted by eight principles (ISO 9000: 2005). Thus, it is possible that 'certified organisations may not implement these principles in similar extents and may exhibit varying patterns of implementation by paying extra attention to some principles that are in the line with their corporate strategies' (Lee et al., 2009: 647). Therefore, managers of organisations should carefully design the ISO 9000 implementation strategy. With a well-developed ISO 9000 strategy, the implementation of the standard can be better aligned with the environment of an organisation so as to accomplish competitive advantages and optimal performance.

In order to achieve the true value associated with quality system implementation, it should be made consistent with organisation's strategic directions. Also, identified barriers should be reduced or eliminated in order attain effective implementation which in turn will result in the expected outcome over time. Also, in enhancing the level of true value of the standard and effective implementation, it is strongly recommended that organisations need to focus on receiving training by professional organisations/ institutions on the true meaning of the standard and the new changes and how these changes can impact organisations (Magd, 2008).

\section{The impact of knowledge orientation}

ISO 9000 has become a favoured system for many organisations embarking on quality management. ISO 9000 Standards are an information-sharing tool that an organisation can 
use to gain the knowledge needed to enhance quality and performance. It also provides a ready framework for ordering and structuring an organisation's knowledge. Successful implementation of a quality management system requires appropriate programme formulation (Addey, 2001; Chen ad Tsou, 2003). The programme related to quality management systems implementation should consider from the early stages of their lifecycle the right activities, in the right order and with the right resource involvement. In this context, Lin and Wu (2005) identify the most important activities within ISO 9001:2000 processes which can facilitate knowledge flow and suggest a knowledge creating model for ISO 9001:2000 that an organisation can use to gain the knowledge needed to enhance quality and performance. It also provides a ready framework for ordering and structuring an organisation's knowledge.

Nonaka and Takuechi (1998) conceptualised that the knowledge in organisations can be identified as tacit or explicit. Tacit or explicit classification of knowledge offers a simple and widely understood classification. Tacit knowledge refers to the experience, intuition, judgment and heuristics that one develops overtime which is embodied in the knower. Tacit knowledge cannot be easily transferred or externalised. It takes place through a long process of deep learning, apprenticeship, socialisation and mentoring. Explicit knowledge, on the other hand, refers to knowledge that is recognised and embodied in the various organisational routines i.e. manuals, procedures, instructions, standards, protocols, etc. This type of knowledge can be easily acquired and transferred. As the role of knowledge and the learning organisation has grown, the tacitness and explicitness of the knowledge in the organisation will become a key strategic consideration in shaping the competitive strategy (Abdullah and Ahmad (2009). For quality management programmes and quality models more useful and more popular is explicit knowledge.

The ISO 9001:2008 standard explicitly requires that all processes and procedures be established, documented, implemented and maintained. In fact, the standard and its requirements become the new source of legitimating organisational routines (Walgenbach, 2001; Anwar and Jabnoun, 2006). The quality manual symbolised the institutionalised system of control of the processes by which the requirements of the customers are met (Mike, 2004). Many studies have positioned that quality assurance including ISO 9000 certification tends to result in greater formalisation and explicitisation (Beck and Walgenbach, 2003; Naveh and Erez, 2004). Explicitisation refers to the preference for embedding the knowledge of performing a specific task in the instructions, procedures and manuals. These documents become the main embodiment, the technical knowledge needed to maintain and improve the quality management system. In fact, explicitisation is consistent with the organisational need to capture as much of knowledge possessed by the workers into organisation memory and routines (Molina et al., 2004). Explicitisation enables knowledge transferability and ensures know-how routines embedded in the actions and practices for carrying out dayto-day quality management system by way of training programmes (Lin and $\mathrm{Wu}, 2006$ ). In fact, in high tacit knowledge organisation, the certification processes are inherently more difficult, as much of the system cannot be described or effectively documented. Without explicit documentation, the system is deemed weak and compliance and auditing are increasingly challenging for auditors. 
The impact of the standard on organisational performance is greatest in organisations that mainly utilise explicit knowledge and is weakest in organisations that mainly utilise tacit knowledge (Abdullah and Ahmad, 2009).

Analyses of literature show that for quality improvement programmes, especially those associated with the requirements of ISO 9000 standards, explicit knowledge is more useful. Very important for successful implementation of quality programmes are learning management leadership, involvement of employees, setting of objectives and planning, infrastructure, development and improvement of the learning process, measurement of learning performance (DeTienne et al., 2004; Hariharan and Cellular, 2005). The organisations may focus on systematic communication with the internal customers and act quickly on what they require. The success of an organisation's quality programme increasingly depends on the leadership. The leaders may act as role models through their ethical behaviours and their personal involvements in planning, communication and coaching (Lo and Chin, 2009, p. 457). The ongoing quality system programme implementation strategy development involves performance goals and action plans that reflect the importance of the quality improvement activities. It is necessary to understand the necessity of participation of line managers in planning and designing of training. Without this participation, training is technique-oriented rather than problem and results-oriented. Establishing infrastructure for learning provides a foundation to support the alignment of goals to satisfy the internal customer's needs and expectations and implementation of programme goals at all organisational levels. Continuous development and improvement of the learning process help organisations communicate customer's requirements, monitor actual knowledge management performance, and make adjustments in prioritising and reallocating resources.

Very important for the successful implementation of a quality system is the performance measurement process. A well-structured performance measurement process provides a linkage between strategies and actions. The links are established by the performance goals developed to encourage employee behaviour to meet the organisation's objectives and facilitate and induce quality learning, by incorporating goal setting feedback as an essential component of the system. Six-phase process-based explicit knowledge management model is identified through analysis as the basis for successful preparation and implementation of quality programmes (Table 1).

Table 1. Six-phase process-based explicit knowledge management model for implementation of quality programmes

\begin{tabular}{|c|l|l|l|}
\hline No. & Process phases & \multicolumn{1}{|c|}{ Necessary activities } & \multicolumn{1}{c|}{$\begin{array}{c}\text { Indicators for control and } \\
\text { measurement }\end{array}$} \\
\hline 1 & $\begin{array}{l}\text { Investigation } \\
\text { of international } \\
\text { customer needs } \\
\text { and expectations }\end{array}$ & $\begin{array}{l}\text { Building of two-way } \\
\text { communication channel } \\
\text { and internal marketing of } \\
\text { international customer needs } \\
\text { and expectations }\end{array}$ & $\begin{array}{l}\text { Shows how well an organisation } \\
\text { determines the needs and expectations } \\
\text { of internal customers with the aim of } \\
\text { formulating a learning management } \\
\text { strategy }\end{array}$ \\
\hline
\end{tabular}




\begin{tabular}{|c|l|l|l|}
\hline 2 & $\begin{array}{l}\text { Learning } \\
\text { management } \\
\text { leadership }\end{array}$ & $\begin{array}{l}\text { Involvement of leaders in } \\
\text { planning, communication } \\
\text { and commitment of a quality } \\
\text { programme }\end{array}$ & $\begin{array}{l}\text { Determines key aspects of learning } \\
\text { management leaders responsibilities } \\
\text { in respect of how leaders set goals and } \\
\text { target performances and communicate } \\
\text { with all levels of related learning } \\
\text { management personnel }\end{array}$ \\
\hline 3 & $\begin{array}{l}\text { Planning for } \\
\text { learning }\end{array}$ & $\begin{array}{l}\text { Setting of objectives of the } \\
\text { quality programme and } \\
\text { formulating of action plans to } \\
\text { guide the implementation at the } \\
\text { relevant levels in organisation }\end{array}$ & $\begin{array}{l}\text { Determines how well an organisation } \\
\text { establishes learning management } \\
\text { objectives and how well it converts its } \\
\text { objectives into action plans }\end{array}$ \\
\hline 4 & $\begin{array}{l}\text { Establishing } \\
\text { infrastructure } \\
\text { for learning }\end{array}$ & $\begin{array}{l}\text { Design and improve workplace } \\
\text { for the learning process. } \\
\text { Establishing infrastructure } \\
\text { for data collection and } \\
\text { measurement }\end{array}$ & $\begin{array}{l}\text { Determines how well an organisation } \\
\text { ensures quality and availability } \\
\text { of needed knowledge for internal } \\
\text { customers and systematically integrates } \\
\text { data and information for tracking daily } \\
\text { operation of learning performance }\end{array}$ \\
\hline 5 & $\begin{array}{l}\text { Management of } \\
\text { learning process }\end{array}$ & $\begin{array}{l}\text { Development and improvement } \\
\text { of learning process }\end{array}$ & $\begin{array}{l}\text { Determines how well an organisation } \\
\text { formulates the people-oriented } \\
\text { knowledge processes for conversion } \\
\text { between individual knowledge and } \\
\text { organisational knowledge to enhance } \\
\text { continuous learning at relevant levels }\end{array}$ \\
\hline 6 & $\begin{array}{l}\text { Learning } \\
\text { performance } \\
\text { competitiveness }\end{array}$ & $\begin{array}{l}\text { Measurement of learning } \\
\text { performance }\end{array}$ & $\begin{array}{l}\text { Determines how well an organisation } \\
\text { evaluates learning process } \\
\text { performance and uses evaluation } \\
\text { results to set priorities and targets } \\
\text { improving the learning process }\end{array}$ \\
\hline
\end{tabular}

In this model, the processes are implemented in sequence for the development of a quality programme in an organisation. Internal customers are the final arbiters of how well organisations implement their quality programme.

Typically, employees receiving quality-training are from different functional areas in the organisation and thus have different vested interests and learning objectives. That is, a training audience is typically heterogeneous as opposed to homogeneous. Therefore, in such situations, training must be tailored to accommodate the unique needs of various elements of the training audience, and to correctly ascertain whether the employees in each segment (or role) have learned what they need to know to directly apply in their specific job (Nanda, 2009).

\section{The influence of maintenance of quality system after implementation}

This period is important if an organisation wants to continuously improve and reap the long-term benefits of having a quality management system in place (Nanda, 2009). There 
is evidence in the literature that the perceived benefits of ISO 9001 quality management systems do decrease over time (Casadesus and Karapetrovic, 2005). They stated that there was no evidence to support that certified organisations progressively experienced more beneficial outcomes from ISO 9001 certification. In fact, results have indicated that, on the opposite side, organisations appear to experience declining benefits over time. Those investigations show how important is correct maintenance of a quality management system during the post-certification period. During this period, emphasis is placed on activities such as management reviews, corrective and preventive actions, internal and external audits, collection and analysis of data, measurement of performance, and continuous improvement. Ab Wahid and Corner (2009) investigated critical success factors and problems in ISO 9000 quality management systems maintenance in service organisations. The results showed that people who comprised top management, other employees, the reward system, team work, continuous improvement, understanding of the ISO 9000 itself, and measurement of performance and communication were all critical success factors for ISO 9000 maintenance and for successful results of a quality management system. Continuous improvement of processes, people and systems are also very important factors for a sustainable quality management system. It is useful to apply other methods and tools in achieving the demanded quality. Miguel and Dias (2009) propose a framework for combining ISO 9001 requirements with quality function deployment. White et al. (2009) suggest using process mapping for analysis and development of processes in not-for-profit organisations.

Quality auditors are in a powerful position to increase the value of a quality system. In general, the questions any auditors ask during the audit are conditioned by the plan they have developed and the strategy taken to discover the answers. There are a number of approaches generally used in conducting internal and external quality system audits and each can be characterised by:

- the way the audit is planned (this affects what the auditor looks at and the order in which the audit is performed);

- the way check lists are produced (this affects what the auditor looks for and the questions the auditor will ask);

- the way the auditor conducts the audit (this affects the speed at which evidence is collected and its significance determined);

- the way the auditor reaches conclusions (this affects the validity of the results).

As each organisation conducting audits will have evolved its own techniques, there are no definitive methods. The main reason for conducting audits is to obtain factual input for management decisions, but the vast majority of audits only produce data for use in granting a certificate, for improving documentation or for enforcing conformity. Most auditors have been exposed to conformity auditing, where the sole objective is to establish whether a specific requirement has been met. They invariably do not provide data for making managerial decisions concerned with staff development, technology, growth, product and processes, because these decisions are based on current performance and often all the audit reveals is current conformity, not current performance. Element-based auditing provides evidence that an organisation has interpreted the elements of the standard into procedures and that the procedures are being followed, but not that planned results have been achieved. Department-based auditing provides some evidence that the organisation has interpreted 
the standard into departmental responsibilities and procedures but not that the planned results have been achieved. Task-based auditing provides evidence that specific tasks have been accomplished but not that the planned results have been achieved.

A more effective is processes-based auditing. The auditor seeks to establish the results the organisation desires to achieve, determines that these results take into account the needs of the customers and the interested parties and then examines the way that processes are managed to achieve these results and improve performance. Doing so, an auditor touches every requirement of the ISO 9001:2008 standard. If evidence is revealed that the organisation is satisfying the customers and other interested parties and is applying the eight quality management principles in the way it runs activities, there will be no sound basis for reporting non-conformities.

Assessments are generally restricted to the scope of the management system and the auditor only interfaces with a company's managers and accessible personnel covered by the system. Auditors do not really communicate or interact with any of the organisation's customers, its shareholders and founders or other providers of finance, its partners, its trade associations, regulatory bodies and host governments, the local community or other parties affected by the business. Thus, how can they actually understand the auditee's performance if they are denied direct access to the organisation's stakeholders?

The objective of some organisations is to achieve ISO 9001:2008 certification as a marketing tool and not as a management tool, no matter whether they conform to the standard or not. In this case, it is clear that a certified quality management system requires feedback from final users in order to operate correctly. Very useful for auditors is to go outside the usual scope of assessment and obtain qualitative feedback from the organisation's key external stakeholders (Peterson, 2005). It is necessary to prepare customer satisfaction questionnaires for information and to speak to some real customers.

The "verification" methodology consists of four stages:

1. Is there policy in place?

2. Is there a system in place to implement the policy?

3. Do records show that the system works in practice?

4. When asked, do the stakeholders agree that the system works and is fair?

Traditional quality management system auditing usually goes as far as the third point - but it is the last step that can really add value for an organisation. Naturally, there are practical difficulties: for example, in identifying stakeholders, an auditor can contact during limited assignments that are willing to help by providing feedback, but there is nothing that cannot be overcome. It is very useful for analysing and evaluating the existing situation to identify areas for improvement.

\section{Conclusions}

1. There is an interesting relationship between the reasons of implementation of ISO 9001 quality management systems and the corresponding performance outcomes. According to the literature, organisations maximise their benefits if they achieve ISO 9001 quality system implementation based on internal motivations. Organisations that 
pursue ISO 9001 quality management system implementation willingly and positively across a broad spread of objectives are more likely to report improved organisation performance than those organisations pursuing ISO 9000 certification in a reactionary mode due to customer pressure.

2. There is a relationship between the values and requirements that underpin the ISO 9001 standard and organisational structure and management orientation. Controloriented organisations get benefits from an ISO 9001 quality system more easily than creativity-oriented organisations. The impact of the standard on organisational performance is the greatest in organisations that mainly utilise explicit knowledge and is the weakest in organisations that mainly utilise tacit knowledge.

3. Successful implementation of a quality management system according to 9000 standards requires appropriate programme formulation. The ISO 9001:2008 standard explicitly requires that all processes and procedures be established, documented, implemented and maintained. For this purpose, explicit knowledge is very useful. Explicit knowledge refers to knowledge that is recognised and embodied in various organisational routines, i.e. manuals, procedures, instructions, standards, protocols, etc. This type of knowledge can be easily acquired and transferred. For quality management programmes and quality models, more useful and more popular is explicit knowledge.

4. Correct maintenance of a quality management system during the postcertification period is very important. During this period, emphasis is placed on activities such as management reviews, corrective and preventive actions, internal and external audits, collection and analysis of data, measurement of performance, and continuous improvement.

\section{References:}

1. Ab Wahid, R.; Corner, J. (2009), Critical success factors and problems in ISO 9000 maintenance, International Journal of Quality and Reliability Management, 26(9), 881-893.

2. Abdullah, H.S.; Ahmad, J. (2009). The fit between organizational structure, management orientation, knowledge orientation, and the values of ISO 9000 standard, International Journal of Quality and Reliability Management, 26(8), 744-760.

3. Addey, J. (2001). Quality management system design: a visionary approach. Total Quality Management \& Business Excellence, 12 (7/8), 849-854.

4. Anwar, S.A.; Jabnoun, N. (2006), The development of a contingency model relating national culture to total quality management, International Journal of Management, 23(2), 272-280.

5. Bhuiyan, N.; Alam, N. (2004), ISO 9000:2000 implementation- the North American experience, International Journal of Quality and Reliability Management, 53(1), 10-17.

6. Beck, N.; Walgenbach, L. (2003). ISO 9000 and formalization: how organizational contingencies affect organisational response to institutional force. Schmalenbach Business Review, 55(4), 294-320. 
7. Bhuiyan, N.; Alam, N. (2005), An investigation into issues related to the latest version of ISO 9000, Total Quality Management, 16 (2), 199-213.

8. Biazzo S. (2005). The new ISO 9001 and the problem of ceremonial conformity: How have audits methods evolved? Total Quality Management \& Business Excellence, 16(3), 381-399.

9. Casadesus, M.; Karapetrovic, S. (2005), An empirical study of the benefits and costs of ISO 9000 compared to ISO 90001/2/3:1994, Total Quality Management, 16(1), 105-120.

10. Chen, J.M.; Tsou, J.C. (2003). An optimal design for process quality improvement: modelling and application. Production Planning and Control, 14(7), 603-612.

11. Chin, S.K.; Choi, W.T. (2003), Construction in Hong Kong: success factors for ISO 9000 implementation, Journal of Construction Engineering and Management, November/December, 599-609.

12. DeTienne, K.B.; Dyer, G.; Hoopes, C.; Harris, S. (2004). Toward a model of effective knowledge management and directions for future research: culture, leadership and CKOs. Journal of Leadership and Organizational Studies, 10(4), 26-43.

13. Dick, G.; Gallimore, K.; Brown, J. (2002). Does ISO 9000 accreditation make a profound difference to the way service quality is perceived and measured? Managing Service Quality, 12 (1), 30-42.

14. Dimara, E.; Sakuras, D.; Tsecouras, K.; Goutsos, S. (2004). Strategic orientation and financial performance of firms implementing ISO 9000. International Journal of Quality and Reliability Management, 21(1), 72-89.

15. Donaldson, L. (2001), the Contingency Theory of Organizations, Sage Publications: Thousand Oaks, CA.

16. Douglas, A.; Coleman, S.; Oddy, R. (2003), The case for ISO 9000, The Total Quality Management Magazine, 15(5), 316-324.

17. EN ISO 9001:2008 E, 2008, Quality management systems - Requirements, CEN management centre: rue de Stassart, 36, Brussels.

18. Fotopulos, Ch. V.; Psomas, E. L. (2010), ISO 9001:2000 implementation in the Greek food sector, TQM Journal, 22(2), 129-142.

19. Ghani, K.A.; Jayabalan, V.; Sugumar, M. (2002), Impact of advanced manufacturing technology on organizational structure, Journal of High Technology Management Research, 13(2), 159-175.

20. Gotzamani, K.; Tsiotras, G. (2002). The true motives behind ISO 9000 certification: their effect on the overall certification benefits and long term contribution towards TQM. International Journal of Quality and Reliability Management, 19(2), 151-169.

21. Hariharan, A.; Cellular, B. (2005). Critical success factors for knowledge management. KM Review, 8(2), 16-19.

22. Hazman, S.A.; Sarina, O. (2008), Public universities governance: the missing parameters, Governance and Leadership in Higher Education, National Science University Publishers, Penang, pp.17-24.

23. Lee, P. K. C.; To, V. M.; Yu, B. T.W. (2009). The implementation and performance outcomes of ISO 9000 in service organizations: an empirical taxonomy, International Journal of Quality and Reliability Management, Vol.26, No.7, pp.646-662. x 
24. Lin C.; Wu, C. (2005), A knowledge creation model for ISO 9001:2000, Total Quality Management \& Business Excellence, 26(7), 646-662.

25. Lin, C.; Wu, C. (2006), Case study of knowledge creation contributed by ISO 9001:2000, International Journal of Technology Management, 16(5), 657-670.

26. Lo, K.C.; Chin, K.S. (2009). User-satisfaction-based knowledge management performance measurement. International Journal of Quality and Reliability Management, 26(5), 449-468.

27. Lopis, J., Tari, J. (2003), The importance of internal aspects in quality improvement, International Journal of Quality and Reliability Management, 20(3), 304-324.

28. Lundmark E., Westelius A. (2006). Effects of quality management according to ISO 9000: A Swedish study of the transit to ISO 9000:2000. Total Quality Management \& Business Excellence, 17(8), 1021-1042.

29. Magd, H.A.E. (2008), ISO 9001:200 in the Egyptian manufacturing sector: perceptions and perspectives, International Journal of Quality and Reliability Management, 25(2), 173-200.

30. Mallak, L.A.; Bringleson, L.S.; Lith, D.M. (1997), A cultural study of ISO 9000 certification, International Journal of Quality and Reliability Management, 14(4), 328-348.

31. Martinez-Costa, M.; Martinez-Lorente, A. (2003), Effects of ISO 9000 certification on firms performance: a vision from the market, TQM and Business Excellence, 14(10), 1179-1191.

32. Miguel, P. A.; Dias, J. C. S. (2009). A proposed framework for combining ISO 9001 quality system and quality function deployment, TQM Journal, 21(6), 589-606.

33. Mike, B. (2004). Get staff involved in quality initiatives. Quality Progress, 37(2), 62-68.

34. Mikulis, J.; Ruževičius, J. (2009). Management systems and competitiveness of a country - Lithuanian context. In Current Issues on Business and Law, Vol. 3 (pp. 2646). Vilnius: VTVK.

35. Molina, L. M.; Montes, F. J. L.; Fuentes, D.M.F. (2004), TQM and ISO 9000 effects on knowledge transferability and knowledge transfer, Total Quality Management, 15(7), 1001-1115.

36. Naveh, E.; Erez, M. (2004). Innovation and attention to detail in the quality improvement paradigm. Management Science, 50(7), 1576-1596.

37. Nonaka, I., Takuechi, H. (1998). The knowledge Creating Company, in Mabey C., Salaman G., Storey J. (Eds), Strategic Human Resource Management, A Reader, Sage, London, p. 102.

38. Nanda, V. (2009), Quality management system handbook for product development companies, CRC Press, Boca Raton, FL.

39. Paterson, F. (2005) Pay closer attention to needs of audit clients. ISO Management Systems, 6(1), 5-9.

40. Poksinska, B.; Dahlgaard, J. J.; Eklund, J. A. E. (2006). From Compliance to ValueAdded Auditing-Experiences from Swedish ISO 9001:2000 certified Organizations. Total Quality Management \& Business Excellence, 17(7), 879-892.

41. Quazi, H.; Jakobs, R. (2004), Impact of ISO 9000 certification on training and development activities, International Journal of Quality and Reliability Management, 21(5), 497-517. 
42. Rodriguez - Escobar J. A., Gonzalez - Benito J., Martinez - Lorente A. R. (2006). An analysis of degree of small companies' dissatisfaction with ISO 9000 certification, Total Quality Management \& Business Excellence, 17(4), 507-521.

43. Ruzevicius, J.; Adomaitiene, R.; Sirvidaite, J. (2004), Motivation and efficiency of quality management systems implementation: a study of Lithuanian organizations, Total Quality Management \& Business Excellence, 15(2), 173-189.

44. Ruževičius, J.; Kasperavičius, J. (2008). The Lithuanian police activities quality improvement. In Current Issues on Business and Law, Vol. 2 (pp. 119-136). Vilnius: TTVAM. $\mathrm{x}$

45. Simpaio, P.; Saraiva, P.; Guimaraes Rodrigues, A. (2009), ISO 9001 certification research: questions, answers and approaches, International Journal of Quality and Reliability Management, 26(1), 35-58.

46. Van der Wiele, T.; Van Iwaarden, J. (2005). Perceptions about the ISO 9000:2000 Quality System Standard Revision and Its Value: Dutch Experience, International Journal of Quality and Reliability Management, 22(2), 101-119.

47. Walgenbach, P. (2001). The production of distrust by means producing trust. Organizational Studies, 22(4), 693-714.

48. White, G.R.T.; Samson, P.; Rowland-Jones, R.; Thomas, A.J. (2009), The implementation of a quality management system in the not-for-profit sector, TQM Journal, 22(2), 101-119.

\section{KOKYBĖS VADYBOS SISTEMŲ İGYVENDINIMO MODELIŲ POVEIKIS VEIKLOS REZULTATAMS}

Santrauka. Literatūroje nurodoma, kad organizacijose dažnai trūksta lankstumo rengiant ir igyvendinant kokybès vadybos sistemas bei mažai išnaudojamos darbuotojų žinios ir igūdžiai. Straipsnyje analizuojami skirtingi kokybès vadybos sistemų diegimo modeliai ịvairaus pobūdžio organizacijose ir veiklos rezultatai šiose organizacijose. Tyrimai rodo, kad organizacijų, taikančių skirtingus kokybės valdymo sistemų diegimo modelius, labai skirtingi veiklos rezultatai. Gerai apgalvota kokybès valdymo sistema turi atsižvelgti ị kokybės sistemos ịgyvendinimo sèkmės faktorius nuo pirmuju planavimo etapų ir procesų numatymo. Yra įdomus ryšys tarp ISO 9001 kokybės vadybos sistemų diegimo ir atitinkamų veiklos rezultatų supratimo. Reikalaujant, kad visi procesai ir procedūros būtų dokumentuojami, ISO 9000 standartas yra neabejotinai dažniausiai siejamas su valdymo orientacija ir organizacijomis, kurios orientuojasi ị aiškiai apibréžtas žinias. Igyvendinant organizacinius mokymosi mechanizmus, organizacijos gali padidinti žinių naudojimo ir pritaikymo galimybes. Tokie mechanizmai leidžia organizacijoms rinkti, analizuoti, kaupti, skleisti ir naudoti organizacijai svarbią informaciją. Labai svarbi yra teisinga kokybès valdymo sistemos priežiūra po jos sertifikavimo. Kokybès auditoriai turi realias galimybes padidinti kokybès valdymo sistemų vertę. Pridètinès vertès auditas ne tik pateikia duomenis, skirtus naudojimui nurodytam sertifikate, bet ir vadybinių sprendimų prièmimui, susijusiems su ekonomika, personalo plètra, technologijomis, ekonomikos augimu, produktų ir procesų naudojimu, nes šie sprendimai priimami remiantis esama veikla.

Adolfas KAZILIŪNAS - Habil. Doctor of Technological Sciences, Professor, Mykolas Romeris University, Faculty of Politics and Management, Professor of Management Institute. 
Research interests: quality management, design of quality management systems, certification and audit.

Adolfas KAZILIŪNAS - Mykolo Romerio universuteto, Politikos ir vadybos fakulteto, Vadybos instituto profesorius, habil. daktaras.

Tyrimų sritys: kokybès vadyba, kokybès vadybos sistemų kūrimas, sertifikavimas ir auditas

Lina VYŠNIAUSKIENE் - lecturer, Institute of Management, Mykolas Romeris University.

Research interests: quality management, management, certification and audit.

Lina VYŠNIAUSKIENĖ - Mykolo Romerio universuteto, Politikos ir vadybos fakulteto, Vadybos instituto lektorè.

Mokslinių interesų sritys: kokybės vadyba, vadyba, sertifikavimas ir auditas. 